\title{
Entre fragmentações identitárias e estruturais: o romance contemporâneo de Adriana Lisboa
}

\author{
Mirian Cardoso da Silva* \\ Lúcia Osana Zolin*
}

\section{A estrutura do romance contemporâneo}

Muito já se tem falado sobre o gênero romanesco e sua capacidade, inscrita em sua própria gênese, de favorecer questionamentos e reflexões acerca de trajetórias e buscas individuais. Em A teoria do romance (2000), o húngaro Georg Lukács, ao refletir sobre tal gênero lança mão dos conceitos de cultura fechada e de cultura aberta, relacionando a primeira às formas épicas clássicas, caracterizadas pela representação de sociedades homogêneas e estáticas, além de sujeitos unos, cujos destinos eram guiados e ditados pelos deuses; e a segunda à ideia de processo, que a forma romanesca pressupõe, marcando o momento em que o homem se abre à construção da sua subjetividade, fazendo questionamentos acerca da própria existência, assinalando um modo de estar no mundo, marcado, quase sempre, pela incoerência e pela fragmentação.

Consciente do seu desajuste em relação ao mundo circundante, o sujeito anseia pela completude, sem, no entanto, alcançá-la na maior parte das vezes. Sendo assim, enquanto a epopeia, replicando a sua própria estrutura, dava forma a existências marcadas pela totalidade, o romance representa, desde a sua configuração estrutural, a expressão de subjetividades fragmentadas em busca de unidade, como observa-se no herói problemático, de que fala Lukács, de caráter degradado, marcado pela inaptidão de realização de seus ideais, à maneira do protagonista de D. Quixote, de Cervantes; assim como o ser desajustado, empenhado em negar o enfrentamento dos conflitos com o mundo, como ocorre com o Werther, de Goethe; ou os heróis dos chamados romances de educação, cujos indivíduos representados se situam entre os tipos acima, caracterizando-se pela busca da reconciliação com a realidade circundante, como é o caso de A montanha mágica, de Tho-

Doutoranda em Letras, área de concentração Estudos Literários na Universidade Estadual de Maringá. E-mail: mikardosoo@gmail.com.

** Pós-Doutora em Letras pela Universidade Federal do Rio de Janeiro (UFRJ). Professora do Departamento de Letras e do Programa de Pós-Graduação em Letras da Universidade Estadual de Maringá. E-mail: luciazolin@yahoo.com.br. 
mas Mann; ou ainda os heróis de romances, como os de Tolstoi, segundo o teórico, representante maior do que ele chama de epopeia moderna, empenhados em atuarem sobre a sociedade para se ajustarem a ela, sem, contudo, resolverem suas questões em face dela.

Passadas várias décadas desde a publicação, em 1965, desse clássico da teoria literária, as ideias aí disseminadas continuam igualmente pertinentes e adequadas. O gênero romanesco vai se desdobrando em sua incompletude - cada vez mais exacerbada - e se adaptando aos contornos dos conflitos dos sujeitos contemporâneos, igualmente incompletos e fragmentados, marcados que são pelas instabilidades decorrentes do contexto em que se encontram inseridos, o da industrialização, o do capitalismo, o da globalização, o das coisas moventes e incertas, enfim. O/a escritor/a contemporâneo/a parece ter, cada vez mais, consciência de que o ato de narrar e o modo de narrar configura-se não apenas como parte de um mundo aberto e em movimento, mas constitui, ele próprio, a sua subjetividade, que se completa com a do/a leitor/a. A desconstrução do narrador tradicional, nesse sentido, funciona, na romanesca contemporânea, como importante estratégia na representação de subjetividades descentradas, fragmentadas e caóticas que emergem desse contexto.

Sobrevivente do mundo épico, as formas narrativas típicas dos romances realistas, pautadas em preceitos de um mundo pleno de sentido e coeso, nas quais o narrador reinava absoluto, conhecedor que era de tudo que dizia respeito às personagens e ao mundo narrado, vão se modificando e se adequando às demandas do tempo. Em face de um mundo marcado por toda sorte de descentramentos - de sujeitos, de instituições, de valores, etc. -, a própria figura do narrador tem seus contornos borrados. Afinal, como narrar com autoridade e coerência identidades e circunstâncias que são fundamentalmente caóticas?

Segundo Adorno (2003, p.55), o "narrador se caracteriza por um paradoxo: não se pode mais narrar, embora a forma do romance exija a narração". Isso porque seria uma pretensão, na contemporaneidade, conferir à narrativa o sentido de um mundo completo. $\mathrm{O}$ status de autoridade que caracterizava o narrador da Antiguidade Clássica e da Idade Média ao narrar fatos heroicos, lendas e mitos não é mais compatível com as incertezas que marcam o tempo presente. Da sua perspectiva, tendo em vista o curso de desenvolvimento desencadeado a partir do século XIX até chegar aos níveis atuais, mesmo que, a princípio, os narradores dos romances busquem a verossimilhança, apresentando conteúdos capazes de evocarem o real, o subjetivismo que lhes marca a consciência e o modo de estar no mundo "não tolera mais nenhuma matéria sem transformá-la”.

Do mesmo modo, Walter Benjamin (1987), partindo de reflexões acerca da obra do escritor Nikolai Leskov, argumenta que a arte de narrar histórias com começo, meio e fim, inscritas em algum tipo de temporalidade, está em extinção: os sujeitos, antes empenhados em produzir conhecimento e experiências comunicáveis, passam a viver mais intensamente sua individualidade. $O$ fato é que, paulatinamente, 
a figura do narrador vai se distanciando, se rarefazendo a partir do começo da modernidade até sair completamente de cena. Estamos falando da pós-modernidade, momento desencadeado mais ou menos em torno dos anos 1980, marcado por escritas híbridas, fragmentadas, centradas em "eus" ávidos por autoconhecimento e descrentes em relação a verdades absolutas e a valores tradicionais.

É o que se pode constatar quando da fruição dos romances de Luci Collin como, por exemplo, Com que se pode jogar (2011) que trata da trajetória de um personagem masculino, que direta e indiretamente determina a vida de três mulheres, cujas histórias são tão díspares entre si como o são em relação àquele que desencadeou as circunstâncias catastróficas cujas consequências tiveram que assimilar. Diante de tanta disparidade e fragmentação identitárias, como centralizar tudo na perspectiva de um/a único/a narrador/a? A solução desse impasse aponta para a fragmentação também do foco narrativo: três histórias, três narradoras cuja relação que estabelecem entre si só é revelada ao/a leitor/a na última página.

A exemplo desse, muitos outros romances contemporâneos se constituem por meio de soluções estéticas fragmentadas, em uma espécie de estratégia de adequação ao mundo fluído, ou líquido de que fala Bauman (2001), cercado por leitores/as ávidos/as por leituras que lhes possam espelhar as angústias, igualmente fragmentadas e difusas. São romances, como os de Collin, que tencionam o monólogo interior e o fluxo de consciência em contextos de múltiplas perspectivas; ou apresentam narradores não confiáveis, caso de alguns criados por Elvira Vigna, como o de Deixei ele lá e vim (2006) que confessa que mente sobre os fatos narrados, de modo que o/a leitor/a se vê impelido/a a intuir a diferença entre a invenção e a realidade, bem como os limites entre o conteúdo do que é narrado e o ato em si de narrar, já que o/a narrador/a conta a história ao mesmo tempo em que a escreve: "Há algumas possibilidades de enredo, aqui, porque, se eu me esforçar, posso contar isto de outro modo" (VIGNA, 2006, p. 41). Outros lançam mão da estratégia da autoficção, em que o imaginário do/da escritor/a se mistura às experiências de fato vividas dando origem a um texto que reivindica para si o desejo de promover o desnudamento de um "eu" que remete ao sujeito que escreve ao mesmo tempo em que dele se afasta. Nos termos de Figueiredo (2013), trata-se do romance autobiográfico pós-moderno, cujos formatos inovadores redundam em narrativas descentradas, fragmentadas, com sujeitos que dizem "eu" sem que saiba exatamente a qual instância enunciativa esse "eu" se refere.

É o caso de A chave de casa (2007), de Tatiana Salem Levy, em que a narradoraprotagonista, sem dúvida alguma, remete à escritora: ambas têm ascendência turca, nasceram em Portugal durante a ditadura salazarista e foram criadas no Brasil. Mas a história, permeada de intensas experiências vivenciadas no âmbito familiar e amoroso, vai muito além: os relatos se intercalam, fazendo referência a espacialidades e a momentos múltiplos, em que a imobilidade e a movência se alternam, conferindo-lhes o tom. Por entre os relatos do relacionamento afetivosexual, transformado em violência, o da doença e morte da mãe, e o da viagem à 
Turquia, em busca das origens familiares, a narradora vai contando sua experiência de uma longa e dolorosa paralisia, provavelmente metafórica, cuja motivação nem é dada ao/a leitor/a conhecer, nem a própria narradora parece discernir com clareza; ora lhe parece provir do acúmulo de solidão, tristeza e dores herdadas de seus ancestrais: "Tenho em mim o silêncio e a solidão de uma família inteira, de gerações e gerações” (LEvy, 2007, p.106); ora lhe parece consequência do excesso de amor doado: "Fui perdendo a mobilidade depois que te conheci. Foi o amor (excedido) que me tirou, um a um, os movimentos do corpo" (Levy, 2007, p. 133).

O doloroso processo que envolve a doença e a morte da mãe funciona como um divisor de águas na sua trajetória, imprimindo-lhe certo desejo de retomar as rédeas da própria história. A voz da mãe já morta, colocada entre parênteses, configura-se como uma interessante solução estética empenhada em projetar ponderações, permeadas de afeto, que caminham na contramão da ótica derrotista da filha, funcionando como uma espécie de alter ego dela, um desejo íntimo de se posicionar a partir de outro ângulo de visão que lhe possibilitasse uma saída.

Tendo recebido do avô a chave da casa da família na Turquia, bem como a missão de ir ao seu encontro, ela parte, não sem antes resistir, em busca das origens familiares, cujos ecos habitam a memória de seus antepassados e, consequentemente, a sua, assombrando-lhe com ancestrais códigos morais e práticas culturais, propagadas, sob o manto do afeto, quase sempre em forma de opressão e de repressão.

Do mesmo modo que a paralisia anteriormente referida parece configurar-se, na economia da narrativa, como metáfora da inércia existencial da personagem, face às múltiplas opressões vivenciadas, a viagem é, por outro lado, metáfora de enfrentamento. Nesse itinerário, a busca da casa ganha foros de busca pelas tradições culturais e genealógicas da família, visando, num certo sentido, a superação de influências restritivas sobre sua trajetória e, de outro lado, o redimensionamento de suas identidades: apesar de não se reconhecer, inicialmente, como turca, passar a questionar a sua brasilidade, ponderar a sua acidental natalidade portuguesa, ela acaba por resgatar-se a si própria.

Também no romance Rakushisha (2007), de Adriana Lisboa, a estrutura do foco narrativo é cambiante, alternando, sem aviso prévio, narradores em primeira e em terceira pessoa, quando não simultaneamente. Trata-se da história de Celina, personagem emblemática do cenário contemporâneo, que conhece Haruki em uma estação do metrô ao questioná-lo sobre o livro que ele lia, Diário de Saga escrito pelo poeta japonês Matsuo Bashô no século XVII. Depois de um bate-papo num café, ele a convida para viajarem juntos ao Japão, terra do autor do diário que ele iria ilustrar. Sem saber exatamente o porquê, ela aceita o convite impensado, mas busca configurar o motivo que a faz atravessar o mundo com um estranho, rumo a um país tão diferente do seu. 
A narrativa marcada pela mobilidade, tanto em relação ao foco narrativo oscilante, quanto aos deslocamentos espaciais empreendidos pelas personagens, é conduzida e inspirada no poeta Bashô, demonstrando a dificuldade deles em se fixarem em algum lugar, imersos que estão no movimento inerente à realidade pósmoderna. Aos poucos, são desveladas as sutilezas da relação de (des)encontro entre Haruki e Celina, sublinhando as dores de cada um, suas buscas e descobertas.

As circunstâncias típicas da pós-modernidade, em que, como já dito, os sujeitos estão imersos - realidades frágeis e transitórias da viagem, do exílio, da solidão em meio à multidão e da contemplação de si - reverberam na estrutura móvel do romance que se desenvolve por meio da perspectiva cambiante entre um narrador onisciente e as reflexões que Celina registra em seu diário, misturadas ao fluxo da consciência e a monólogos interiores. A história suave e cheia de sentimento que vai tecendo aponta para um processo de escrita semelhante ao de Bashô - um dos mestres do haicai tradicional - que escrevia enquanto viajava, caracterizando-se, assim, como um poeta itinerante. Ela, em igual medida, viaja em suas memórias e no tempo, conferindo à estrutura temporal da narrativa o mesmo caráter de mobilidade/fragmentação. Dito de outro modo, a fragmentação estrutural do romance, observada, sobretudo, na construção do foco narrativo e da temporalidade, põe em evidência as questões que influenciam nas construções identitárias das personagens, desvelando as descontinuidades das trajetórias de Celina e Haruki.

Por sua vez, Hanói (2013), também de Adriana Lisboa, põe em cena um narrador em terceira pessoa que focaliza ora uma personagem, ora outra, e embora não lhes domine a totalidade dos sentimentos e emoções, cumpre o papel de permear, na sutileza da narrativa, as angústias de cada uma diante da iminência da morte. Trata-se de David, um trompetista de 32 anos, filho de um brasileiro imigrante ilegal nos Estados Unidos com uma mexicana, que recebe a notícia do câncer cerebral no mesmo dia em que conhece Alex, a funcionária de um mercado asiático com quem irá se relacionar.

David não é apenas um personagem contemplativo, mas age através de atitudes simples como dar um aquário e um peixe ao vizinho, tentando desapegar-se das coisas materiais que o cercavam e constituíam sua vida anterior e encontrar sentido à nova realidade que se apresenta; um novo caminho que trilha na morte, que vem acompanhada de contemplação de si mesmo e questionamento do mundo.

Também está presente o teor de mobilidade, pois ambos os personagens se encontram sempre em deslocamento, em meio a consultórios médicos, cafés, praças, ruas, parques, lanchonetes, escola, pizzaria, shows, agência de viagem, metrôs. No entanto, em Hanói, a viagem é muito mais simbólica por ser utilizada por David enquanto um movimento que norteará suas descobertas e aprendizagens no árduo caminho em direção à morte. Nessa perspectiva, a viagem se configura como a busca por compreender a si mesmo, seus sentimentos diante de sua finitude iminente, sua falta de laços afetivos sinceros e reais, e a construção destes com novas pessoas, com as quais se depara em seus deslocamentos por Chicago. 
Conforme expresso anteriormente, o narrador onisciente organiza a narrativa, mas não a domina plenamente. Isto porque o tema do romance, a iminência da morte, possibilita uma reflexão profunda sobre a fragilidade do ser humano e de sua efemeridade, levando a uma leveza sutil na narrativa ao abordar os enfrentamentos do protagonista diante da sua existência e toda sua fragilidade. Esta incapacidade do narrador de tomar as rédeas da narrativa parece remeter e reforçar a impossibilidade de ação das personagens diante da frágil existência no mundo, como será analisado a seguir.

\section{Fragmentações identitárias e estruturais em Rakushisha e Hanói}

Rakushisha apresenta uma estrutura narrativa cambiante entre a voz do narrador onisciente e outra em primeira pessoa, a de Celina que escreve um diário contando as experiências sentidas e vivenciadas ao aceitar o convite inusitado de Haruki logo após conhecê-lo em uma estação de metrô e viajar com ele para o Japão, onde vivenciará o encontro consigo própria enquanto se desloca pelas ruas de Kyoto. Hanói apresenta dois personagens: David e Alex, que se conhecem também em um não-lugar nos termos de Augé (2005), um mercadinho asiático, e cujas identidades tanto pessoais quanto culturais são fragmentadas devido às consequências do fato de ambos serem filhos de imigrantes e em terras americanas. A notícia da morte iminente que assola um, acaba por atingir também a outra. A estratégia narrativa para iluminar o drama é a do discurso indireto livre que, como é da sua natureza, permite flagrantes das angústias vivenciadas, sem que marcas linguísticas ou estruturais sinalizem o início ou término das falas, pensamentos, fluxos de consciência ou monólogos interiores. Em ambos os romances a fragmentação identitária das personagens é replicada na estrutura da própria narrativa. Nesse último, a sutileza com que o narrador constrói o perfil psicológico de David em face da proximidade da própria morte corrobora o cuidado que pede um tema tão delicado para o ser humano. Comparado a fragmentação da perspectiva narrativa de $R a$ kushisha, Hanói possui uma estrutura mais fixa, necessária para representar o desconcerto trazido pela iminência da morte da maneira que Adriana Lisboa propõe.

No caso de Rakushisha, a escolha da dupla perspectiva narrativa traz um estatuto ambíguo para a obra, uma ambiguidade advinda desse "eu protagonista" que é uma "espécie de testemunha de si mesmo que, a todo momento, pode estar falseando o que narra" (ARRIGUCCI, 1998, p. 18), daí a confiabilidade da narrativa ser questionável. Também o narrador onisciente faz questão de narrar o mesmo acontecimento tanto pelo viés de Celina quanto de Haruki, buscando construir a história por dois ângulos, levando a esse deslocamento constante de foco:

Naquela tarde, em pé, meio apertado no meio dos outros passageiros, tirou o livro que havia dado início a tudo. (...) Houve uma rápida parada na estação Flamengo. Até Haruki descer na estação Botafogo e ouvir uma 
voz ao seu lado (...) desculpa, mas é que eu fiquei tão curiosa. Isso aí que você lia é japonês ou chinês? (LisBOA, 2007, p. 24-25).

Um homem de traços orientais lia o livro, em pé, no metrô. Celina abaixou os olhos para os próprios pés. (...) Veio a curiosidade quase irresistível de saber o que era, de quem era, do que tratava. (...) Celina se endireitou e avançou um pouco. Ao saírem, ainda na plataforma, ela juntou os passos aos dele: desculpa, mas é que eu fiquei tão curiosa. Isso aí que você lia é japonês ou chinês? (LisBOA, 2007, p. 31-32).

Além de mostrar pelas duas perspectivas, o mesmo fato é contado diversas vezes no romance: "Um dia, no metrô do Rio de Janeiro, uma mulher lhe perguntou, quando Haruki desceu na estação Botafogo: desculpa, mas é que eu fiquei tão curiosa. Isso aí que você lia é japonês ou chinês?” (LisBoA, 2007, p. 97). A simples classificação dos narradores nas categorias de narrador onisciente e protagonista não exaure, todavia, a questão. Tal estrutura parece reverberar nas páginas do romance as marcas do mundo fluído que serve de contexto à história.

O contexto histórico-cultural em que o romance é produzido é o da pósmodernidade constituído sobre os alicerces de uma sociedade do consumo; como consequência, rodeia-se de informações e tecnologias que se inovam a cada dia, impelindo os sujeitos a consumirem mais e mais rapidamente. O que remete ao que Fernandes (2009, p. 306) declara como "fascínio pelo imediatismo", a necessidade de o sujeito consumir produtos que logo serão substituídos por outros e assim sucessivamente. Trata-se de um estado de coisas que repercute nas próprias relações sociais (BAUMAN, 2004). Os indivíduos passam a viver no mundo digital, nas redes sociais, afastando-se cada vez mais da possibilidade de construir de laços afetivos duradouros.

Daí o romance também se transformar para atender as novas necessidades dos/as novos/as leitores/as. Adorno (2003) e Bakhtin (2010) ponderam que se trata de uma demanda pertinente do romance que sendo, por excelência, um gênero inacabado, acumula outros gêneros e características, se adaptando e se transformando conforme o homem, a sociedade e o mundo se transformam. Sendo assim, a maneira tradicional de narrar, discutida anteriormente, torna-se, cada vez mais, uma impossibilidade, abrindo espaço para novas experimentações tanto estéticoestruturais quanto em relação à linguagem. Há um entremear de vozes narrativas no romance, que intercalam os "eu, nós, ele, ela", como se observará nos romances em análise, dificultando estabelecer uma categoria de narrador exata. Além disso, não há cronologia temporal, e sim tonalidade rítmica rápida e fluída, nas quais são inseridas imagens, trechos de outros livros, poemas, letras em itálico, maiúsculas, frases curtas, como parágrafos curtos, que caracterizam a fugacidade do tempo pós-moderno (FERNANDES, 2009).

A narrativa pós-moderna transfigura o romance tradicional, e tem, em primeira instância, o anseio pela experimentação, exigindo que o leitor participe da cons- 
trução do texto. Isso pode ser observado na estrutura do romance Rakushisha, permeada pelos haicais de Matsuo Bashô, poeta que, segundo Sousa (2007), é considerado um dos mestres do haicai, tendo como princípio filosófico a arte da vida como um trilhar de caminhos, um modo de viver no mundo.

Bashô publicou sob o pseudônimo de Sôbô e Tôsei, apareceu em diversas antologias japonesas entre 1662-1672. Lançou o livro The Seashell Game, em que compila haicais. Adota o nome de Matsuo Bashô, após receber de seu discípulo uma bananeira, que planta perto da cabana humilde onde ele morava, e começa a fazer viagens, tornando-se, assim, um poeta itinerante. Algumas de suas obras são: The records of a Wather-Exposed Sleten (1684) e Sendas de Oku (1689). Segundo Sousa (2007), por nascer em uma cultura que intentava o sentido da vida e das coisas no silêncio e também no vazio, Bashô "samurai e monge zen, colocou em prática no haikai tudo aquilo que aprendeu e alimentou a sua alma durante a vida. Tornouse o maior poeta de haikai do Japão, transformando essa forma poética em um caminho (DO), uma via de acesso a uma experiência" (SousA, 2007, p.33). Em 1691, ele escreve seu Diário de Saga, um dos cinco diários de viagem escrito pelo poeta, hospedado nos arredores de Kyoto, em um local chamado Rakushisha, a Cabana dos Caquis Caídos, que pertencia a Kyorai, o discípulo de Bashô:

Diz a lenda que Kyorai tinha cerca de quarenta pés de caqui crescendo no jardim de sua cabana em Saga, subúrbio de Kyoto. Tinha acertado a venda de frutos, certo outono em que as árvores estavam carregadas, mas na véspera do dia em que deveria entregá-los uma forte tempestade caiu, à noite. Não sobrou um único caqui. Desse dia em diante passou a chamar sua casa de Rakushisha, a Cabana dos Caquis Caídos (LisBOA, 2007, p. 35).

Tendo sido convidado para ilustrar o Diário de Bashô, que receberia a primeira tradução brasileira, Haruki aceita o desafio que acaba por redundar em outro: conhecer as suas origens. A obra de Bashô, desta forma, torna-se parte da trajetória dos protagonistas, reverberando-lhes a fluidez e os deslocamentos tanto de Haruki por Tokyo e de Celina por Kyoto, quanto da própria estrutura textual. Assim, o fluxo da narrativa, além de fragmentado na questão do narrador e do tempo, o é pelas inserções dos haicais, que sempre entrecortam o desenvolvimento da ação. Bashô não só impulsiona a narrativa, as ações e as reflexões das personagens, como também pode ser visto como personagem do romance, porquanto há capítulos nomeados como "Bashô" (p. 83); "Yukiko e Bashô" (p.137); "Haruki e Bashô" (p. 179); e o último capítulo que se fecha com "Bashô" (p. 189). Embora não haja uma personificação do poeta, as suas poesias são as que dão mobilidade às trajetórias das personagens, como observado no seguinte trecho:

Haruki me disse que conhece a tradutora deste diário de Bashô. Me disse isso com a voz de viés. Com a voz desencontrada das palavras. Dever ser a mulher que ele ama. 


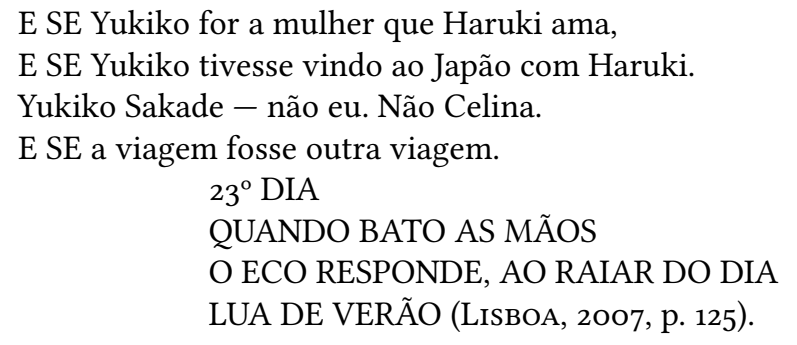

Percebe-se, assim, junto com a inserção dos haicais, algumas outras características como as letras maiúsculas e as frases curtas, com parágrafos curtos e capítulos também, reiterando a fluidez da narrativa e a mobilidade da leitura, configurando a narrativa em suas estruturas contemporâneas em que se abrem as já ditas experimentações. Além disso, o próprio diário de Celina mistura-se com o de Bashô, como se observa no seguinte trecho: "Que nenhum japonês me visse fazendo aquilo. A moça ocidental desajeitada e desastrada. $22^{\circ}$ DIA Chuva pela manhã. Nenhuma visita, e em minha solidão eu me divirto escrevendo a esmo" (LisBoA, 2007, p. 104, grifo nosso).

O teor de mobilidade se apresenta nos próprios trechos do diário do poeta, em que Bashô relata os deslocamentos através do espaço: "Bonchô chega de Kyoto. Kyoria retorna a Kyoto" (p. 48), "A monja Ukô chega para ver o festival do norte de Saga, Kyorai vem de Kyoto" (p. 55), "Quando a noite se aproxima, Kyorai volta para Kyoto" (p. 62), "Senna retorna a Ôtsu. Fumikuni e Jôsô vêm nos visitar" (p. 101), "Otokuni vem me ver e fala de Musashi-no-kuni em Edo" (p. 103).

Os fatos, então, são narrados em um fluxo descontínuo, com idas e vindas no tempo, a partir da memória de Celina, que conta, por intermédio de seu diário, os acontecimentos e suas angústias diante do fato de estar em um país diferente. Incapaz de se comunicar por não falar japonês, sua situação de isolamento acarreta a solidão e, concomitantemente, o encontro com a memória de fatos que antes tentava ocultar dos pensamentos: "o cão que há muito já se tornou um punhado de ossos delicados e uma leve memória, uma memória vagando sozinha pela superfície do mundo, fantasma do impulso, eco daquele jeito que era seu jeito de existir: mordendo" (LisBoA, 2007, p. 139). Assim, a memória dos personagens, e seu fluxo desconexo de tempo, faz com que a narrativa transite entre o tempo presente e passado, além de retornar diversas vezes a um mesmo acontecimento.

Hanói, também contextualizado na agitada Chicago da pós-modernidade, apresenta suas personagens em constante deslocamentos por não-lugares. Há uma alternância de perspectivas narrativas entre David e Alex, que carregando o peso de angústias distintas, ele com sua morte próxima, ela com um filho para criar, o trabalho, os estudos e as memórias da guerra vietnamita que povoa o imaginário da família, irão somar suas angústias. O narrador onisciente focaliza uma personagem e logo depois, durante aquele mesmo momento, a outra, permitindo ao/à leitor/a conhecer concomitantemente ambos, como se um completasse a narrativa do outro: 
Alguém tinha contado a David a história do sujeito diagnosticado com uma doença grave a quem o médico só havia dado um ano de vida (LisBoA, 2013, p. 9).

Naquele mesmo dia, algumas horas mais tarde, o dono de um pequeno mercado asiático em Little Vietnam foi chamar a atenção da garota que atendia no caixa (LisBOA, 2007, p. 13).

Em uma obra, cujo tema é a morte, poderia o narrador valer-se de um tom mais mórbido, ou um narrador protagonista adotar um tom sentimental ou fatalista. No entanto, o narrador onisciente, cujo foco narrativo transita entre David e Alex, aproximando ou afastando seus pensamentos ou flagrando-os rememorando o passado, funciona muito bem no sentido de construir o drama e a angústia existencial do protagonista David diante da morte:

Não arrancou as roupas e saiu gritando pelas ruas, parte de um grupo de pessoas às quais finalmente se permitia certa falta de juízo. Não agarrou a bunda da enfermeira que fazia o possível para fingir que não era bonita atrás de um jaleco estampado com Plutos. Não subiu no telhado da clínica. Só o que fez foi procurar um café ali perto, surpreso com o modo como tudo continua idêntico. O céu não tinha ficado cor de abóbora nem o chão tremia nem godzillas pisoteavam os carros (LisBOA, 2013, p.11).

Trata-se de um tom adequado para descrever os movimentos interiores do protagonista, abrangendo-lhe a vontade de não recair no lugar comum do desespero de quem descobre que tem pouco tempo de vida. Dá vazão a seu desejo consciente de aceitação do inevitável e de aprender a lidar com sua nova realidade:

David estava bem informado. Tinha, inclusive, lido sobre as tais fases clássicas pelas quais o doente terminal passa. A última dessas fases era a aceitação, então por que não começar por ela, e evitar todo o transtorno das outras quatro? Nada de negação ou raiva, nada de tentar barganhar um pouco mais de tempo - principalmente nada de depressão (LisBOA, 2013, p. 124).

A construção psicológica da personagem aponta para a sutil delicadeza que o narrador imprime à situação, destacando o desejo dele de não imergir na depressão, mas encarar a morte e, assim, aprender mais sobre a vida. Em certos momentos, constrói-se como narrador não confiável, utilizando-se de dúvidas referentes às personagens, demonstrando não conhecer totalmente os seus pensamentos e desejos e, desse modo, abrindo espaços para as inferências do/a leitor/a:

O que Huong não entendia era que David tinha começado a pensar em Hanói como uma espécie de cemitério de elefantes. E para o cemitério os elefantes vão sozinhos. As pessoas vão sozinhas para a sua 
própria morte. Ninguém morre acompanhado. Ou não era nada disso? Será que ele tinha certeza? Mas, do contrário, o que era Hanói, então? (LisBoA, 2013, p. 193-4).

Em outros, borra propositalmente os limites entre a própria voz e os monólogos interiores das personagens, relativizando certezas e construindo a atmosfera intimista que a situação evoca:

Coisas ruins iam acontecer, e ela não ia querer estar por perto, David tinha dito. Mas ela queria estar por perto. Querer não era um verbo sinônimo de pensei bem, refleti, pesei os prós e os contras e concluí que. Era um verbo físico, não mental. Era um verbo que se conjugava com o estômago, com os músculos, com o frio das mãos. Faça o possível. Poderia ser título de um livro de autoajuda. Talvez fosse. Faça o possível e pronto. Se tudo era basicamente isso, fazer o possível enquanto possível, não? (LisBOA, 2013, p.186).

O enredo, mais homogêneo que o de Rakushisha, conduz com espontaneidade os sentimentos, emoções e pensamentos dos protagonistas, descartando o supérfluo, como as coisas materiais das quais David vai se despojando ao longo da narrativa, e assim desenha-lhes as trajetórias, em meio a suas angústias existenciais e o aprendizado daí decorrente. Em igual medida, a estrutura temporal da narrativa é também mais linear, pois a história começa com a descoberta de David sobre sua doença, desenvolve-se no entorno da aprendizagem que a eminência da morte lhe oferece e termina com a concretização da morte tão anunciada. Entretanto, nesse percurso, as personagens, atingidas pelas sutilezas do dia a dia, são tocadas por memórias do passado e vão reconstruindo suas raízes genealógicas, suas angústias e suas buscas identitárias: "o avô americano de Alex se chamava Derrick. Sargento Derrick. Essa era toda a informação que tinha dele, além do fato de ser bonito" (LisBoA, 2013, p. 80). Além disso, mesmo com a fatalidade da morte de David, o romance tem um final em aberto, com Alex, Max e Bruno na cidade que intitula o romance, para onde Alex vai, em uma tentativa de se despedir de David e onde os três "sairiam para conhecer Hanói” (p. 238).

\section{Considerações finais}

Os romances Rakushisha e Hanói são emblemáticos da pós-modernidade, nos quais aparecem as impossibilidades e as possibilidades narrativas a que se refere Adorno (2003) em suas reflexões aqui retomadas. Embora o narrar seja inerente ao gênero romanesco, as transformações que tal ato pode comportar acompanham o devir temporal, descortinando as trajetórias e possibilidades do sujeito pós-moderno. Esses romances carregam na sua própria estrutura as características pungentes do mundo contemporâneo, refletidas na fluidez da narrativa, das 
relações e dos sujeitos, bem como na solidão que lhes marca a trajetória nas sociedades pós-modernas. Recursos como o monólogo interior e o fluxo da consciência corroboram a construção de narradores que, apesar de onisciente, não podem tudo saber ou dominar, já que tal totalidade de conhecimento é incompatível com o contexto em que emergem personagens, narradores e narrativas.

E é obedecendo a essa lógica que tais instâncias se constroem sob os alicerces das incertezas, dos deslocamentos de ordem temporal, espacial e identitária. Em outras palavras, sob o signo da fragmentação e da desestruturação das regras de classificação dos elementos da narrativa.

Assim, a impossibilidade de representar um realismo, ou narrar próximo da verdade, caracteriza a narrativa contemporânea, fazendo com que haja uma perquirição pelo que Arrigucci irá chamar de realismo de essência, algo que transcende a realidade reitificada, "defrontando-se então com o paradoxo de ter que narrar, porque a forma do romance exige a narração, numa época em que isto se apresenta como uma impossibilidade" (ARIGGUCCI, 1998, p.30).

\section{Referências}

Adorno, Theodor. Posição do narrador no romance contemporâneo. In: Notas de Literatura I. Tradução Jorge de Almeida. São Paulo: Duas Cidades; Ed. 34, 2003. p. $55-63$.

ArRigucci, Davi. Teoria da narrativa: posições do narrador. Fornal de Psicanálise, São Paulo, v. 31, n. 57, p. 9-43, set. 1998.

AugÉ, Marc. Não-Lugares: introdução a uma antropologia da supermodernidade. Tradução Maria Lúcia Pereira. 5. ed. Campinas: Papirus, 2005.

Bauman, Zygmunt. Modernidade liquida. Tradução Plínio Dentzien. Rio de Janeiro: Zahar, 2001.

Bauman, Zygmunt. Amor líquido: sobre a fragilidade dos laços humanos. Rio de Janeiro: Jorge Zahar, 2004.

BAKHtin, Mikhail. Epos e Romance. In: Questões de literatura e de estética: a teoria do romance. São Paulo: Hucitec, 2010.

Benjamin, Walter. Obras escolhidas: magia e técnica, arte e política. São Paulo: Brasiliense: 1987 .

Collin, Lucy. Com que se pode jogar. Ed. Kafka: Curitiba, 2011.

Cury, Maria Zilda Ferreira. Cartografias literárias: Tsubame, de Aki Shimazaki, e Rakushisha, de Adriana Lisboa. 2012. Disponível em: http://www.revistas. unilasalle.edu.br/index.php/interfaces/article/viewFile/436/304. Acesso em: 18 jul. 2015 . 
Friedman, Norman. O Ponto de Vista na Ficção: o desenvolvimento de um conceito crítico. Revista USP, São Paulo, n. 53, p. 166-182, mar./mai. 2002.

Fernandes, Giséle Manganelli. O pós-modernismo. In: Bonnici, Thomas \& ZoLIN, Lúcia Osana (orgs.). Teoria Literária: abordagens históricas e tendências contemporâneas. 3. ed. Maringá: Eduem, 2009.

Hall, Stuart. A identidade cultural na pós-modernidade. Tradução Tomaz Tadeu da Silva e Guacira Lopes Louro. 11. ed. Rio de Janeiro: DP\&A editora, 2011.

LEvy, Tatiana Salem. A chave de casa. Rio de Janeiro: Editora Record, 2008.

LisboA, Adriana. Rakushisha. Rio de Janeiro: Objetiva, 2014.

LisboA, Adriana. Hanói. Rio de Janeiro: Objetiva, 2013.

LuKÁcs, G. A teoria do romance: um ensaio histórico-filosófico sobre as formas da grande épica. (Tradução, posfácio e notas de José Marcos Mariani de Macedo). São Paulo: Duas Cidades; Ed. 34, 2000.

Vigna, Elvira. Deixei ele lá e vim. São Paulo: Companhia das Letras, 2006.

Recebido em 30 de julho de 2018.

Aprovado em 9 de abril de 2019.

\section{Resumo/Abstract/Resumen}

\section{Entre fragmentações identitárias e estruturais: o romance contemporâneo de Adriana Lisboa}

\section{Mirian Cardoso da Silva, Lúcia Osana Zolin}

Este artigo propõe algumas reflexões sobre o romance contemporâneo, chamando atenção para o fato de o mesmo replicar o contexto pós-moderno em que emerge no modo como representa identidades e elementos estruturais fragmentados. Isso implica dizer que as formas épicas que ilustraram por muito tempo o ato de narrar tiveram que se adequar à instabilidade do tempo, por meio de narradores híbridos, não confiáveis, de onisciência seletiva e/ou relativizada, fluxo de consciência, fragmentação espacial, estrutural e temporal, entre outras características do romance contemporâneo que, não raras vezes, impõe dificuldades às classificações tradicionais. Assim, sob a luz das ponderações de teóricos e pesquisadores como Adorno (2003), Rosenfeld (1973), Bauman (2001), Hall (2011) entre outros, nosso intuito é problematizar essas questões tomando como corpus principal de análise os romances Rakushisha (2007) e Hanói (2013), de Adriana Lisboa.

Palavras-chave: pós-modernidade, estrutura narrativa, fragmentação, identidades, Adriana Lisboa. 


\section{Between Identity and Structural Fragmentations: Adriana Lisboa's Con- temporary Novels}

\section{Mirian Cardoso da Silva, Lúcia Osana Zolin}

This article offers some reflections on the contemporary novel, calling attention to the fact that in itself it replicates the postmodern context in which it was created through its representation of fragmented structural identities and elements. This implies that the epic forms that have long illustrated the act of narrating have had to adapt to the instability of time, through unreliable hybrid narrators, selective and / or relativized omniscience, flow of consciousness, and spatial, structural and temporal fragmentation, among other characteristics of the contemporary novel that, in many cases, make traditional classifications more difficult. So, taking into account the ideas of theorists and researchers such as Rosenfeld (1973), Bauman (2001) and Hall (2011), among others, our intention is to problematize these questions, taking as our corpus of analysis the novels Rakushisha (2007) and $\mathrm{Ha}$ noi (2013), by Adriana Lisboa.

Keywords: post-modernity, narrative structure, fragmentation, identities, Adriana Lisboa.

\section{Entre fragmentaciones identitarias y estructurales: la novela contempo- ránea de Adriana Lisboa}

\section{Mirian Cardoso da Silva, Lúcia Osana Zolin}

Este artículo trata de realizar algunas reflexiones sobre la novela contemporánea, señalando para el hecho de que la misma replica el contexto post moderno que emerge en el modo en el que la identidad y los elementos estructurales fragmentados son representados. Ello implica afirmar que las formas épicas que las han ilustrado durante muchos años y el propio acto de narrar hayan tenido que adaptarse a la instabilidad del tiempo, através de narradores híbridos, no confiables, de omnisciencia selectiva o relativizada, flujo de consciencia, fragmentación espacial, estructural y temporal; entre otras características de la novela contemporánea, que en numerosas ocasiones impone dificultades a las clasificaciones tradicionales. De este modo, con base en las ponderaciones de teóricos e investigadores como Adorno (2003), Rosenfeld (1973), Bauman (2001) y Hall (2011), entre otros, nuestro objetivo es problematizar esas cuestiones utilizando como corpus principal del análisis las novelas Rakushisha (2007) y Hanói (2013), de Adriana Lisboa.

Palabras clave: postmodernidad, estructura narrativa, fragmentación, identidades, Adriana Lisboa. 